the National Parks lies in the failure of the Government to provide, under the National Parks and Access to the Countryside Act of 1947, the finance required to make the provisions of the Act effective. Under that Act the responsibility for the National Parks was placed within the planning system set up by the Town and Country Planning Act of 1947 instead of the national system envisaged by the Hobhouse Committee. The counties provide two-thirds of the Committee members and almost all the funds, although some of these counties are among the poorest in the country.

Nevertheless, the system has worked surprisingly well, though it is obviously unfair to expect local authorities to take a national point of view, and invariably set the national interest before local interests, particularly at heavy cost to the ratepayers who elect them. The advantages of close association with local interests are such, however, that in view of this experience, it seems highly probable that, given quite moderate Government support, sufficient, for example, to ensure the provision of adequate planning staff and a reasonable contribution to the capital costs of positive projects of development, the existing system could well be continued with success. Much could be done if the National Parks Commission had an annual sum of even as little as $£ 100,000$, in place of the present $£ 20,000$ (with some $£ 5,000$ in Exchequer grants to the National Parks), which it could use at its discretion, either in helping the weaker authorities to strengthen their planning staffs, or in assisting projects which, at present, the park planning authorities hesitate to undertake because of their fear to place excessive burdens on local ratepayers for the benefit of outsiders.

Such a system admittedly is pragmatic rather than the ideal national system, in which national purposes and projects are financed directly from national funds, as Mr. F. H. Hayman advocated on March 30. Admittedly, the development and preservation of the National Parks is often too dependent on the finance committee of the county councils concerned, as $\mathrm{Mr}$. Hayman pointed out ; but to transfer the whole cost of the National Parks to national funds is not the only way of overcoming the difficulty, and if such a transfer lost local interest in, and support for, the National Parks the price might well lead to local misunderstanding and opposition. Mr. Hayman did not, however, appear to advocate quite such a drastic step though he made it clear enough that local resources and prejudices should not determine the objectives and purposes of a national undertaking.

In replying on this debate, Sir Keith Joseph asked for specific examples of projects which were now being frustrated by lack of funds, but claimed that direct Parliamentary grant, and not discretionary payment, was the appropriate way to finance public schemes. $\mathrm{He}$ confirmed that the Minister would look at all proposals made to him for amending the Act and said that he was at present seeking more information from the National Parks and the National Parks Commission to assist in this review. Sir Keith was emphatic that there was much more which could be done by the individual Park Committees which would receive Exchequer aid up to 75 per cent, but he thought the time might well have come to extend the legislative framework in some ways. Nevertheless, he did not think that finance was the only answer. Vigilance, effective administration and an imaginative approach must also play an important part, and probably the main value of both debates lies in the extent to which they demonstrate the need for public co-operation and understanding, and for such unceasing vigilance if the purposes of other Parks or Nature Reserves are to be served.

The whole subject was further discussed in the House of Lords on April 19 on a motion of Lord Silkin, who again stressed the importance of adequate financial provision. Lord Feversham also pointed out that existing provisions were completely inadequate, either to prevent or to control fires on heaths and moors, and Lord Dalton, who agreed as to the need for adequate financial provision, also pressed the claims of the long-distance footpaths. Lord Chorley specifically suggested that the National Parks Commission should have an annual sum of $£ 150,000$ at its disposition, and like most other speakers was critical both of the Electricity Authorities and of afforestation, though tribute was freely paid to the sympathetic attitude of the Forestry Commission and its present chairman. Earl Jellicoe, who replied on the debate for the Government, added little to what had been said in the Commons by Sir Keith Joseph, but referred particularly to Lord Feversham's suggestion of a direct Treasury grant to the National Parks Commission.

\title{
THE RESEARCH COUNCIL OF ALBERTA
}

$\mathrm{T}$ HE forty-first annual report of the Research Council of Alberta covers the year $1960 *$, and includes a list of publications for 1956-60, and lists of members of Advisory and Technical Advisory Committees and of the staff of the Research Council. The Petroleum Division of the Fuels Branch has largely completed its work on the movement of oil in the presence of water in a pipe-line, and studies on capsule pipe-line transportation indicate that the presence of capsules in a flowing stream does not significantly alter pressure gradients, nor does the moving core appreciably distort the flow in the annulus. The capsule velocity appears to depend directly on capsule

* Research Council of Alberta. Forty-first Annual Report, 1960 Pp. $v+55$. (Report No. 80.) (Edmonton: Research Council of Pp. v +55. (1 length and inversely on capsule diameter. The Division has also completed the first major phase in developing a generalized mechanism for the control of composition and accumulation of crude oils and natural gases in sedimentary basins, and the light paraffinic oils, which are usually found in positions corresponding to the areas of maximum depth of sedimentary basins, appear to owe their paraffinic constitution to the extensive action of oxidation and microbiological attack, both of which tend to destroy the less-resistant components of the developing crude oil. With the Coal Division the Petroleum Division is studying the transport of mixtures of pulverized coal and oil, while the Coal Division has also studied the combustion of pulverized fuel, the crystal structure 
and magnetic properties of coal chars, the plastic properties of Alberta coking coals and coal blends. Work on the mechanisms of coal pyrolysis and carbon formation is expected to bear directly on carbon production from low- and medium-rank coals, and physico-chemical investigations on humic acids from coal have shown that simple coupling reactions can convert humic acids into water-soluble materials without otherwise altering their chemical properties, and that humic acids can be made to yield fivemembered cyclic anhydrides.

The Natural Gas Division has been engaged largely in the separation of gases by selective adsorption on porous solids and with catalytic reactions in the adsorbed state, particularly the catalytic conversion of cyclopropane to propylene on crystalline aluminosilicates. The Groundwater Division has provided information which assisted in meeting several serious water-shortages, while the programme of the Geology
Division included a study of the fossil content, distribution and physical make-up of Cretaceous rocks, the study of iron deposits and examination of $a$ gypsum deposit at Mount Heed. The reconnaissance soil survey of the Hines Creek map sheet was completed, as well as an exploratory soil-survey by helicopter of some 10 million acres in the northwestern part of the Province, while the Soils Division has also co-operated in work on the classification of forest sites and the irrigation of Solonetzic soils. The basic cloud-physics programme, with special reference to hail, included establishment of an enlarged mesobarograph network covering 10,000 sq. miles, upper wind observations stations at Penhold, Rimbey and Rocky Mountain House, and an expanded hailstone collection network. Synoptic investigations on hail now permit some differentiation of storms as related to certain areas to low-level convergence and moving cold-front activity.

\section{ERADICATION OF MALARIA}

$\mathrm{A}$ LTHOUGH progress towards world-wide malaria eradication has, in general, been satisfactory, there are some malaria eradication programmes that have failed to develop as speedily as they could. A report of the World Health Organization's Expert Committee on Malaria is mainly concerned with the reasons for these failures, and with methods of increasing the efficiency of eradication programmes*.

The technical, operational and administrative causes of failure are analysed in detail, and it is emphasized that success depends not only on careful planning and meticulous execution of the programme but also on the full support of the national authorities at every stage. This must be ensured at the outset by a signed undertaking from the Government.

The criteria given in the Committee's seventh report for discontinuing spraying operations and starting the consolidation phase are amplified and a fresh eriterion added, namely, that surveillance should be fully established and adequate. The measures undertaken should include the passive as well as the active detection of cases, this being the only way to ensure that all areas are reached and that observations are continuous. With the view of reducing the costs of the consolidation phase without sacrificing efficiency, the report recommends that the World Health Organization should study the costs by heads of expenditure in as many countries as possible, and should encourage the detailed analysis of costs both by activity and by heads of expenditure in selected representative countries.

The report reaffirms that eradication may be considered to have been achieved "when an adequate surveillance mechanism has not discovered any evidence of transmission or residual endemicity, despite careful search, during three consecutive years". The criteria of eradication given in the sixth report of the Expert Committee on Malaria are re-examined; while the basic principles remain unchanged, the criteria are re-defined and expanded in order to cover the needs of special situations that have been met in practice. With the aim of establishing an official register of areas where eradication has

* World Health Organization. Technical Report Series, No. 205. Expert Committee on Malaria-Eighth Report. Pp. 50. 2 Swiss francs; 38. $6 d . ; 0.60$ dollar. (Geneva: World Health Organization; London: H.M.S.O., 1961.) been achieved, recommendations are given on the methodology of inspection and certification.

In countries where the administrative structure and the health services are still in the developmental stage, a "pre-eradication programme" may be necessary to create suitable conditions for the success of malaria eradication. An outline of such a programme is given, and it is suggested that an international team should be provided to advise the Government and, if necessary, to carry out the initial stages of the programme.

Health education forms an essential part of a malaria eradication programme; it must reach all levels of the population from the outset of the campaign and be continued throughout the consolida. tion and maintenance phases, in order to ensure continued co-operation of the public at a time when interest in malaria will have begun to wane. The report advocates that provision should be made for a special staff to run health education programmes under the malaria eradication programme.

The establishment of a standard terminology for use in evaluation and surveillance was considered by the Committee to be highly desirable, and it was recommended that the World Health Organization set up a drafting Committee to undertake this task.

The report directs attention to the value of chemotherapy in the attack phase of eradication programmes as well as in the later stages. The 4-aminoquinolines remain the most effective drugs and no significant changes are recommended in the regimen for radical cure. The use of salt medicated with chloroquine shows promise. Research is needed on the improved use of available drugs and to discover compounds with an improved action against malaria parasites.

It is believed that, in some countries, a reduction in the standard dosage of DDT ( $1 \mathrm{gm} . / \mathrm{sq} . \mathrm{m}$.) used in spraying might be possible, but no such reduction should be made until appropriate field trials have provided unequivocal evidence that this would not jeopardize the success of the eradication programme.

Finally, the report considers the relation of simian to human malaria, particularly the recent experimental transmission of malaria from the lower monkeys to man. It is concluded that the practical importance of a simian reservoir of malaria is likely to be small. 